\title{
17. The Make-or-Buy Decision: Lessons from Empirical Studies
}

\author{
PETER G. KLEIN
}

\section{INTRODUCTION}

The "transaction cost" theory of the firm introduced by Coase (1937) has become a standard framework for the study of institutional arrangements. The Coasian framework helps explain not only the existence of the firm, but also its size and scope. Why, in Coase's (1937, pp. 393-94) words, "does the entrepreneur not organize one less transaction or one more?" Some firms are highly integrated: IBM, for example, produces many of its components and software and maintains its own sales force for mainframe computers. Others are much more specialized: Dell Computer outsources virtually all its hardware and software components, selling directly to end users through its catalog and website, while the shoe company Reebok owns no manufacturing plants, relying on outside suppliers to make its products. U.S. manufacturing and service companies are increasingly contracting with specialized information technology firms for their computing and data warehousing needs, spending $\$ 7.2$ billion on outsourced computer operations in 1990. Standard and Poor's estimates total worldwide outsourcing for 2003 at $\$ 170$ billion. $^{1}$

Why do some firms choose a vertically integrated structure, while others specialize in one stage of production and outsource the remaining stages to other firms? In other words, should a firm make its own inputs, should it buy them on the spot market, or should it maintain an ongoing relationship with a particular supplier? Traditionally, economists viewed vertical integration or vertical control as an attempt to earn monopoly rents by gaining control of input markets or distribution channels. The transaction cost approach, by contrast, emphasizes that vertical coordination can be an efficient means of protecting relationship-specific investments or mitigating other potential conflicts under incomplete contracting. As transaction cost economics was developed in the 1970s and 1980s, a stream of empirical literature emerged explaining the "make-or-buy decision" using transaction cost reasoning. (The traditional approach has generated relatively few empirical applications beyond analyses of particular antitrust cases.) This chapter surveys the empirical literature

${ }^{1}$ These and other examples are provided by Brickley, Smith, and Zimmerman (2004, p. 515).

435

C. Ménard and M. Shirley (eds.), Handbook of New Institutional Economics, 435-464.

(C) 2005 Springer. Printed in the Netherlands. 
on vertical boundaries, focusing on the transaction cost approach and emphasizing the most important results, while highlighting the challenges that remain. ${ }^{2}$

\section{THE THEORY OF VerTICAL BOUNDARIES}

Coase was the first to explain that the boundaries of the organization depend not only on the productive technology, but also on the costs of transacting business. In the Coasian framework, the decision to organize transactions within the firm as opposed to on the open market - the "make or buy decision"- depends on the relative costs of internal versus external exchange. The market mechanism entails certain costs: discovering the relevant prices, negotiating and enforcing contracts, and so on. Within the firm, the entrepreneur may be able to reduce these "transaction costs" by coordinating these activities himself. However, internal organization brings other kinds of transaction costs, namely problems of information flow, incentives, monitoring, and performance evaluation. The boundary of the firm, then, is determined by the tradeoff, at the margin, between the relative transaction costs of external and internal exchange. In this sense, firm boundaries depend not only on technology, but also on organizational considerations; that is, on the costs and benefits of various contracting alternatives.

This is explained in detail in Paul Joskow's chapter in this volume. A few highlights are worth mentioning here to guide the reader through the empirical literature. First, economic organization, both internal and external, imposes costs because complex contracts are usually incomplete- they provide remedies for only some possible future contingencies. This obviously applies to written contracts for all but the simplest forms of trade. It also applies to relational contracts, agreements that describe shared goals and a set of general principles that govern the relationship (Goldberg, 1980; Baker, Gibbons, and Murphy, 2001), and to implicit contracts, agreements that while unstated, are assumed to be understood by all sides. Second, contractual incompleteness exposes the contracting parties to certain risks. Primarily, if circumstances change unexpectedly, the original governing agreement may no longer be effective. The need to adapt to unforeseen contingencies constitutes an additional cost of contracting; failure to adapt imposes what Williamson (1991a) calls "maladaptation costs."

The most-often-discussed example of maladaptation is the "holdup" problem associated with relationship-specific investments. ${ }^{3}$ The holdup problem figures

\footnotetext{
${ }^{2}$ Earlier surveys of this literature, from a variety of perspectives, include Joskow (1988a), Shelanski and Klein (1995), Rindfleisch and Heide (1997), Masten and Saussier (2000), Vannoni (2002), Boerner and Macher (2002), and David and Han (2004). Masten (1996) collects many of the important earlier articles.

${ }^{3}$ More generally, contractual difficulties can arise from several sources: "(1) bilateral dependence; (2) weak property rights; (3) measurement difficulties and/or oversearching; (4) intertemporal issues that
} 
prominently Williamson's $(1975,1985,1996 b)$, Klein, Crawford, and Alchian's (1978), and Grossman and Hart's (1986) interpretations of the transaction cost theory. Investment in such assets exposes agents to a potential hazard: If circumstances change, their trading partners may try to expropriate the rents accruing to the specific assets. Rents can be safeguarded through vertical integration, where a merger eliminates any adversarial interests. Less extreme options include long-term contracts, partial ownership, or agreements for both parties to invest in offsetting relationship-specific investments. Overall, several governance structures may be employed. According to transaction cost theory, parties tend to choose the governance structure that best controls the underinvestment problem, given the particulars of the relationship.

In this sense, transaction cost economics may be considered the study of alternative institutions of governance. Its working hypothesis, as expressed by Williamson (1991b, p. 79), is that economic organization is mainly an effort to "align transactions, which differ in their attributes, with governance structures, which differ in their costs and competencies, in a discriminating (mainly, transaction cost economizing) way." Simply put, the contractual approach tries to explain how trading partners choose, from the set of feasible institutional alternatives, the arrangement that best mitigates the relevant contractual hazards at least cost.

The theory is fleshed out by specifying which governance structures go with which transactions. Transactions differ in the degree to which relationshipspecific assets are involved, the amount of uncertainty about the future and about other parties' actions, the frequency with which the transaction occurs, and so on. Each matters for the preferred institution of governance, although the first — asset specificity—is particularly important. Williamson (1985, p. 55) defines asset specificity as "durable investments that are undertaken in support of particular transactions, the opportunity cost of which investments is much lower in best alternative uses or by alternative users should the original transaction be prematurely terminated." ${ }^{4}$ This could describe a variety of relationship-specific investments, including both specialized physical and human capital, along with intangibles such as R\&D and firm-specific knowledge or capabilities.

Governance structures include markets, hierarchies, and hybrids. The pure anonymous spot market suffices for simple transactions such as basic commodity sales. Market prices provide powerful incentives for exploiting profit

can take the form of disequilibrium contracting, real time responsiveness, long latency and strategic abuse; and (5) weaknesses in the institutional environment" (Williamson, 1996b, p. 14). Each of these has the potential to impose maladaptation costs. Foreseeing this possibility, agents seek to reduce the potential costs of maladaptation by matching the appropriate governance structure with the particular characteristics of the transaction.

${ }^{4}$ Klein, Crawford, and Alchian's (1978) definition is similar, though they omit the qualifier "much." Essentially they define a relationship-specific asset ("specialized asset") as any asset that generates appropriable quasi-rents; i.e., any asset whose value to its current renter exceeds its value to another renter. 
opportunities and market participants are quick to adapt to changing circumstances as information is revealed through prices. When relationship-specific assets are at stake, however and when product or input markets are thin, bilateral coordination of investment decisions may be desirable and combined ownership of these assets may be efficient. Ownership is completely combined in the fully integrated firm. The transaction cost approach maintains that such hierarchies offer greater protection for specific investments and provide relatively efficient mechanisms for responding to change where coordinated adaptation is necessary. Compared with decentralized structures, however, hierarchies provide managers with weaker incentives to maximize profits and normally incur additional bureaucratic costs.

Alternatively, partial alignment may be achieved within an intermediate or hybrid form such as long-term contracts, partial ownership agreements, franchises, networks, alliances, and firms with highly decentralized assignments of decision rights. Hybrids attempt to achieve some level of central coordination and protection for specific investments while retaining the high-powered incentives of market relations.

\section{STRATEGIES FOR EMPIRICAL RESEARCH}

Most of the empirical work on the make-or-buy decision adopts the transaction cost framework and follows the same basic model. The efficient form of organization for a given economic relationship - and, therefore, the likelihood of observing a particular organizational form or governance structure-is seen as a function of certain properties of the underlying transaction or transactions: asset specificity, uncertainty, frequency, and so on. Organizational form is the dependent variable, while asset specificity, uncertainty, complexity, and frequency are independent variables. Specifically, the probability of observing a more integrated governance structure depends positively on the amount or value of the relationship-specific assets involved and, for significant levels of asset specificity, on the degree of uncertainty about the future of the relationship, on the complexity of the transaction, on the frequency of trade, and possibly on some aspects of the institutional environment.

Organizational form is often modeled as a discrete variable- "make," "buy," or "hybrid," for example-though it can sometimes be represented by a continuous variable. Of the independent variables, asset specificity has received the most attention, presumably because of the central role it plays in the transaction cost approach to vertical integration. Williamson (1991a) distinguishes among six types of asset specificity. The first is site specificity, in which parties are in a "cheek-by-jowl" relationship to reduce transportation and inventory costs and assets are highly immobile. The second, physical asset specificity, refers to relationship-specific equipment and machinery. The third is human asset specificity, describing transaction-specific knowledge or 
human capital, achieved through specialized training or learning-by-doing. The fourth is brand-name capital, reflected in intangible assets reflected in consumer perceptions. The fifth is "dedicated assets," referring to substantial, generalpurpose investments that would not have been made outside a particular transaction, the commitment of which is necessary to serve a large customer. The sixth is temporal specificity, describing assets that must be used in a particular sequence.

\section{Data and Methods}

Among the common empirical proxies for asset specificity are technical specifications like product complexity, qualitatively coded from survey data or quantitatively assigned by inspection, as a proxy for physical asset specificity (Masten, 1984; Bigelow, 2001); worker-specific knowledge, again coded from survey data, as a proxy for human asset specificity (Monteverde and Teece, 1982a, 1982b; Masters and Miles, 2002); physical proximity of contracting firms, as a proxy for site specificity (Joskow, 1985, 1987, 1988b, 1990; Spiller, 1985; González,-Diaz, Arruñada, and Fernández, 2000); and spatial and temporal proximity (Masten, Meehan, and Snyder, 1991; Pirrong, 1993; Hubbard, 1999). Other proxies, such as fixed costs or "capital intensity," have more obvious limitations and are rarely used. Where asset specificity cannot be easily measured, concentration has been used in single-industry studies to capture situations where small-numbers bargaining situations are likely to appear (Ohanian, 1994). Common proxies for uncertainty include sales variance (Levy, 1985; Anderson and Schmittlein, 1984) and some measure of technological uncertainty, such as the frequency of changes in product specification and the probability of technological change (Walker and Weber, 1984; Crocker and Reynolds, 1993).

The empirical literature includes qualitative case studies, quantitative case studies focusing on a single firm or industry, and econometric analysis of cross-sectional or panel data from multiple firms or industries. Williamson's (1976) study of cable TV franchising in Oakland, California and Coase's (2000) reinterpretation of the G.M.-Fisher Body case are examples of the first category, while Masten's (1984) investigation of contracting practices in a large aerospace corporation and Saussier's (2000) study of electricity contracts are examples of the second. ${ }^{5}$ Cross-industry analyses include Levy's (1985) study of manufacturing and John and Weitz's (1988) paper on forward integration into distribution.

\footnotetext{
${ }^{5}$ Other case studies on vertical integration include Stuckey (1983) on the aluminum industry, Palay (1984) on rail shipping, Gallick (1984) on tuna processing, Joskow (1985) on coal-burning electric plants, Goldberg and Erickson (1987) on petroleum coke, Masten and Snyder (1993) on shoes, Pirrong (1993) on ocean shipping, Ohanian (1994) on pulp and paper, Ménard (1996) on poultry, and Martinez (2002) on poultry, egg, and pork.
} 
Case studies comprise the bulk of the studies on the make-or-buy decision, primarily because the main variables of interest-asset specificity, uncertainty, frequency-are difficult to measure consistently across firms and industries. In many of the early studies these characteristics were estimated based on surveys or interviews: for example, a manager might be asked to rate the degree to which an investment has value in outside uses, on a Likert-type 1 to 7 scale. Such data are of course subject to the general limits of survey data; namely, that they are based on the respondents' stated beliefs, rather than on their beliefs or valuations as revealed through choice. More important, since these measurements are based on ordinal rankings, it is hard to compare them from industry to industry. What is ranked as a relatively specialized asset in one firm may be rated differently in another firm or industry. Similarly, what one firm considers a comparatively uncertain production process may be the standard operating environment in another. Multi-industry studies may therefore contain variables that are labeled the same thing but are really incommensurable, or, conversely, may contain variables that are identical but labeled differently.

While avoiding the problem of inconsistent measurement across industries, case studies have their own problems. The classification of discrete variables like "make-or-buy," for example, may require more discretion by the researcher than economists are comfortable with. And, of course, the evidence from individual cases may not apply to other cases. Still, the cumulative evidence from different studies and industries is remarkably consistent with the basic transaction cost argument, though naturally there remain outstanding puzzles, challenges, and controversies. ${ }^{6}$

\section{Are All Organizations "Efficient"?}

A more general problem with the empirical literature on vertical integrationor, for that matter, any aspect of organizational form-is that we usually observe only the business arrangements actually chosen. If these arrangements are presumed to be efficient, then we can draw inferences about the appropriate alignment between transactional characteristics and organizational form simply by observing what firms do. Indeed, the early empirical work on the transaction cost approach implicitly assumed that market forces work to cause an "efficient sort" between transactions and governance structures. Williamson (1988, p. 174) acknowledges this assumption, while recognizing that the process of transaction cost economizing is not automatic:

\footnotetext{
${ }^{6}$ Moreover, a case study is often better than the alternative: no study. In Simon's (1992, p. 1504) words, "Although case studies are only samples of one, such samples are infinitely more informative than samples of none... [V]alid hypotheses are much more likely to emerge from direct, intimate encounter with organizations than from speculation."
} 
The [transaction cost] argument relies in a general, background way on the efficacy of competition to perform a sort between more and less efficient modes and to shift resources in favor of the former. This seems plausible, especially if the relevant outcomes are those that appear over intervals of five and ten years rather than in the very near term. This intuition would nevertheless benefit from a more fully developed theory of the selection process. Transaction cost arguments are thus open to some of the same objections that evolutionary economists have made of orthodoxy.

Still, he maintains that the efficiency presumption is reasonable, offering the argument - analogous to Friedman's famous (1953) statement on the selection process - that inefficient governance arrangements will tend to be discovered and undone. Concerning vertical integration, for example, Williamson (1985, pp. 119-20) writes that "backward integration that lacks a transaction cost rationale or serves no strategic purposes will presumably be recognized and will be undone," adding that mistakes will be corrected more quickly "if the firm is confronted with an active rivalry."

Recently, researchers have begun to examine this conjecture more closely, looking to see if appropriately organized firms - that is, firms that match transactional characteristics to governance structures as the theory says they shouldreally do outperform the feasible alternatives. Several papers use a two-step procedure in which organizational form (in particular, the relationship between transactional characteristics and governance structure) is endogenously chosen in the first stage, then used to explain performance in the second stage. By endogenizing both organizational form and performance this approach also mitigates the selection bias associated with OLS regressions of performance on firm characteristics. ${ }^{7}$

One important performance measure, in light of Williamson's conjecture regarding the selection process, is firm survival. Silverman, Nickerson and Freeman (1997), for example, show that transaction cost efficiency is positively correlated with firm survival in the for-hire trucking industry, while Bigelow (2001) examines outsourcing arrangements in the U.S. automobile industry and finds that transactions that are appropriately aligned tend to last longer than inappropriately organized ones.

This evolutionary approach sheds considerable light on the processes by which organizations adapt and change, along with the costs of misalignment or maladaptation. However, reliance on evolutionary models introduces additional problems. In many cases, survival may not be the best measure of performance, compared with profitability or market value. Poorly performing firms may survive due to inefficient competitors, regulatory protection, or legal barriers to exit such anti-takeover amendments or an overprotective bankruptcy code. In short, efficient alignment between transactions and governance should be expected

\footnotetext{
${ }^{7}$ Papers using a two-stage approach (such as Heckman's selection model) in this fashion include Masten, Meehan, and Snyder (1991), Poppo and Zenger (1998), Saussier (2000), Nickerson, Hamilton, and Wada (2001), Sampson (2001), Macher (2001), and Yvrande-Billon (2004).
} 
only if the selection environment is strong. Moreover, when market conditions change rapidly and unexpectedly, ex post survival may not be a good measure of ex ante efficiency; a particular organizational form may be right for the times, but the times change. Indeed, the optimal organizational forms may be those that adapt most readily to new circumstances (Boger, Hobbs, and Kerr, 2001). ${ }^{8}$

\section{EVIDENCE ON THE MAKE-OR-BUy DECISION: A SAMPLER}

\section{Component Procurement}

The decision to make components internally or procure them on the open market was the first topic studied extensively within the transaction cost framework. Early efforts by Monteverde and Teece (1982b) and Masten (1984) use samples of components, coded as either made or bought, along with proxies for asset specificity such as worker-specific knowledge and component complexity as rated by industrial engineers. Each paper uses a probit model to test the relationship between in-house production and asset specificity, along with uncertainty and other control variables, and each finds that asset specificity is a statistically significant predictor of vertical integration.

Refinements to this basic approach include distinguishing among types of uncertainty and among types of asset specificity. Walker and Weber (1984) study automobile component procurement and find that uncertainty about production volume raises the probability that a component is made in-house, but "technological uncertainty," measured as the frequency of changes in product specification and the probability of technological improvements, has little effect. Masten, Meehan, and Snyder (1989) compare relative importance of relationship-specific human and physical capital. Also studying automobile production, they find that engineering effort, as a proxy for human asset specificity, appears to affect the integration decision more than physical or site specificity. Klein (1988), in a discussion of the G.M.-Fisher Body case, also suggests that specific human capital in the form of technical knowledge was a major determinant of G.M.'s decision to buy out Fisher.

Indeed, the relationship between G.M. and Fisher Body in the 1920s is the most commonly cited example of a holdup problem solved by vertical integration. Both Klein, Crawford, and Alchian (1978) and Williamson (1985, pp. 11415) explain G.M.'s buyout of Fisher in terms of the specific physical assets that accompanied the switch from wooden- to metal-bodied cars. The account in Klein (1988) is somewhat different, emphasizing specific human capital. Langlois and Robertson (1989) also criticize the earlier account of the G.M.Fisher relationship, arguing that systemic uncertainty, rather than asset specificity, was the motive for vertical integration. Helper, MacDuffie and Sabel

\footnotetext{
${ }^{8}$ An emerging literature on firms as experiments makes the case that organizational change-even the reversal or "undoing" of previous actions — can be consistent with efficient behavior (Mosakowski, 1997; Boot, Milbourn, and Thakor, 1999; Matsusaka, 2001; Klein and Klein, 2002).
} 
(2000) suggest that vertical integration promoted collaborative learning, while Casadesus-Masanell and Spulber (2000) argue it improved the coordination of production and inventories. Interestingly, as Gibbons (2000) points out, few studies investigate the relationship between Fisher and G.M. after the acquisition. An exception is Freeland (2000), who maintains that the Fisher brothers successfully held up G.M. after they became employees. (See below for more on the continuing controversy over this case.)

Other papers document a similar link between integration and R\&D, which usually involves specific human capital (Armour and Teece, 1980; Joskow, 1985; Pisano, 1990). Asset specificity is associated with tighter vertical coordination in many industries, including electricity generation (Joskow, 1985; Saussier, 2000), aerospace (Masten, 1984), aluminum (Stuckey, 1983; Hennart, 1988), forestry (Globerman and Schindt, 1986), chemicals (Lieberman, 1991), engineering (Lyons, 1995), trucking (Nickerson and Silverman, 2003), offshore oil gathering (Hallwood, 1991), information technology (Ulset, 1996), electronic components (Weiss and Kurland, 1997), construction (González-Diaz, Arruñada, and Fernández, 2000), and even stock exchanges (Bindseil, 1997).

Many of these studies include controls for other possible determinants of vertical structure such as market structure, scale and scope economies, and other industry characteristics, and the impact of asset specificity usually remains statistically (and economically) significant. As discussed above, the latest papers also try to minimize selection bias and the effects of unobserved heterogeneity though improved econometric procedures.

Nearly all the studies cited above are focused, single-industry case studies. A few studies have used cross-sectional or panel data to estimate the effects of transactional characteristics on vertical integration using multi-industry data. An early effort by Levy (1985) uses the ratio of value-added to sales as a cross-industry measure of vertical integration ${ }^{9}$; the number of firms and amount of R\&D spending as measures of asset specificity; and the variance of sales as a measure of uncertainty. Using data from 69 firms representing 37 industries, he finds each of the independent variables to have a statistically significant effect on the likelihood of vertical integration. Macmillan, Hambrick, and Pennings (1986) obtain very similar results with a larger sample. Harrigan (1986), by contrast, finds sales variability to result in a lower chance of vertical integration, although she does not include a measure for asset specificity.

Accounting constructs like the ratio of value-added to sales, however, are problematic as measures of vertical integration. Value-added figures are reported inconsistently across firms and industries, and there are several accepted methods for computing value-added ratios. ${ }^{10}$ Caves and Bradburd (1988) construct a more complicated cross-industry measure of integration based on an

\footnotetext{
${ }^{9}$ A fully vertical integrated firm will have a value-added-to-sales ratio of one, while a firm that procures components externally will have a smaller ratio.

${ }^{10}$ See the discussion in Bender (2002).
} 
input-output matrix of distribution shipments across several industries. They use this metric to compare asset specificity, small-numbers bargaining conditions, and risk as determinants of vertical integration. They find asset specificity and small-numbers situations, but not risk, to be significant. Hypotheses based on contractual hazards thus do well in their study as compared to competing approaches. Unfortunately, their procedures are exceptionally data-intensive and may not be feasible in many cases. Other potentially fruitful approaches use financial data on merging firms' pre- and post-merger performance, either to study the gains from merger as a function of asset specificity (Spiller, 1985) or to examine the likelihood of merger as a function of pre-merger bilateral relationships (Weiss, 1992).

A problem with these cross-sectional studies is that they cannot control for time and for unobserved firm-specific characteristics. Using panel data can overcome this limitation. González-Diaz, Arruñada, and Fernández (2000) assemble a panel of Spanish construction firms over a six-year period and study the use of independent subcontractors. They regress the percentage of subcontracting on a distance-based measure of asset specificity, a measure of uncertainty, timeand firm-fixed effects, and other control variables. They find that asset specificity, but not uncertainty, explains most of the outsourcing decision, even when controlling for unobserved heterogeneity. Other studies using panel data, such as Ohanian's (1994) investigation of vertical integration in the U.S. pulp and paper industry and Lafontaine and Shaw's (1999) study of franchise contracting, also support transaction cost explanations even when fixed effects are included. These studies suggest that the generally recognized relationship between asset specificity and vertical control is probably not driven by unobservable firmspecific factors.

\section{Forward Integration into Marketing and Distribution}

While economists typically think of vertical integration as backward integration into components, materials or $\mathrm{R} \& \mathrm{D}$, forward integration into marketing and distribution may be just as important. As Anderson and Gatignon discuss in their chapter in this volume, several studies of integration of marketing channels have used transaction cost reasoning. Anderson and Schmittlein (1984) consider two marketing alternatives for an electronics component producer: the use of employees as a direct sales force (a form of vertical integration), or reliance on independent manufacturers' representatives. This choice is regressed on managers' perceptions of the importance of specific human capital, sales volume uncertainty, and measurement uncertainty (all based on survey data), each of which is predicted to increase the likelihood of a direct sales force. Both specific human capital and measurement uncertainty are statistically significant, though sales uncertainty is not. Another study by Anderson (1985), also on the electronics industry, finds the same basic results, as does work by John and Weitz (1988) using data from a variety of industrial-product industries. Regan (1997) looks at the insurance business and finds that independent 
sales agencies are more common when relationship-specific investment data processing and communications systems are less important. Fein and Anderson (1997) use transaction cost reasoning to show that geographic and brand restrictions serve to protect manufacturers' and distributors' specific reputational capital.

As Holmström and Milgrom (1994) point out, however, the evidence from many of these studies is consistent not only with the transaction cost model, but also with a multitask principal-agent model in which certain clusters of attributes (here, high-performance incentives, worker ownership of assets, and worker freedom from direct controls) go together. Still, the fact that the evidence in marketing and distribution is so similar to the evidence from backward integration into manufacturing and supplies suggests that the transaction cost interpretation should not be easily dismissed.

Marketing and distribution depend on other factors as well, of course. Muris, Scheffman, and Spiller's (1992) study of the carbonated beverage industry finds that the shift from independent bottlers to captive subsidiaries during the late twentieth century can be explained without reference to changes in physical asset specificity or site specificity. Instead, they account for the shift in terms of the emergence of national cola markets, which required greater coordination of advertising and promotional activities. Along with changing technologies in cola production and distribution (namely, falling transportation and communication costs), it was this need for more centralized decision-making - for given levels of asset specificity - that explains the change toward a more vertically integrated industry.

\section{Contracts and Contractual Design}

The earliest literature on the make-or-buy decision-starting with Coase (1937) - treated external sourcing and in-house procurement as polar opposites. Firms were modeled as choosing, as expressed by the title of Williamson's influential (1975) book, between "markets and hierarchies." And yet, we observe firms choosing a variety of intermediate or hybrid forms of organization, such as long-term contracts, partial ownership agreements, franchises, networks, alliances, and other combinations. A good theory of the make-or-buy decision must also explain under what circumstances firms choose one of these intermediate forms.

In the transaction cost approach, a hybrid such as a long-term contract represents a blend, or compromise, between the benefits of centralized coordination and control and the incentive and informational advantages of decentralized decision-making (Williamson, 1991a; Ménard, 2004). For certain types of transactions an intermediate form of governance is appropriate. For instance, under conditions of asset specificity but negligible uncertainty, long-term contracts may be an effective means of mitigating opportunism. When asset specificity and uncertainty are both high, however, contracts may be insufficiently flexible, leading to vertical integration instead. 
Some key issues related to the choice between market, hierarchy, and contracts (or other hybrids) are presented below. For a more detailed treatment of the relevant econometric issues see Saussier's chapter in this volume.

\section{Why Contract?}

Surprisingly, while there is an extensive empirical literature explaining contractual form - duration, completeness, complexity, and other attributes-in terms of transaction costs (see Saussier, this volume, for a survey), the choice between contract and vertical integration or spot-market procurement has received less attention. An exception is the continuing controversy surrounding the purchase of Fisher Body by G.M. in 1926. Klein, Crawford, and Alchian (1978) and Klein (1988) cite the case as a classic example of vertical integration designed to mitigate holdup in the presence of asset specificity. Fisher refused to locate its plants near G.M. assembly plants and to change its production technology in the face of an unanticipated increase in the demand for car bodies, leading G.M. to terminate its existing ten-year supply contract with Fisher and acquire full ownership. Coase (2000), revisiting the original documents, argues instead that the contract performed well, and was gradually replaced with full ownership only to get Fisher's top managers (the Fisher brothers) more closely involved in G.M.'s other operation.

Coase (2000) reveals that the original ten-year supply contract included provisions that G.M. would acquire 60 percent of Fisher's stock and that three of the five members of Fisher's finance committee would be appointed by G.M. Moreover, in 1921 one of the Fisher brothers became a director of G.M., with two other brothers joining him in 1924, one of whom became president of G.M.'s Cadillac division. A fourth brother was added to the board in 1926 when G.M. acquired the remainder of Fisher's stock. As Coase points out, the interests of the two companies were sufficiently aligned during the period covered by the original contract that it is unlikely that Fisher would have used the contract to extract rents from G.M. Also, contrary to the conventional understanding of the case, Fisher did in fact build eight new body plants between 1922 and 1925 that were close to G.M. facilities and had incentives to use the most efficient technology available. In short, G.M. did not acquire the remaining 40 percent of Fisher's stock in response to an inappropriate alignment between transactional attributes and an existing governance structure. Rather, the long-term contract signed in 1919 was adequate for mitigating holdup in the face of asset specificity and uncertainty, and was replaced by vertical integration for secondary reasons.

A few papers study the choice between contracts and other hybrids such as partial ownership agreements or "equity linkages" for conducting R\&D. Pisano (1990) argues that partial ownership dominates contracts under certain combinations of asset specificity, uncertainty, the number of trading partners, and other variables. Equity linkages are more likely when R\&D is to be done during collaboration and when collaboration encompasses multiple projects and less likely when there are more potential collaborators. Oxley $(1997,1999)$ 
shows that the choice between contractual and equity-based vertical alliances is largely explained by the costs of contracting.

\section{Contractual Design}

Given that contracts are used, what provisions should they contain, how long and how complete should they be, and so on? An influential series of papers by Joskow $(1985,1987,1988 \mathrm{~b}, 1990)$ focuses on duration and price-adjustment provisions in agreements between coal suppliers and coal-burning electrical plants. He examined a large sample of coal contracts and found that contracts tended to be longer, all else equal, when relationship-specific investments (here, site specificity and dedicated assets) are at stake. Crocker and Masten (1988) find the same result for the natural gas industry. More generally, they argue that efficient contract duration depends on the costs of contracting; contract terms become shorter, for example, as uncertainty increases. ${ }^{11}$

Another important contractual dimension is incompleteness. As discussed above, the transaction cost approach holds that all complex contracts are necessarily incomplete; otherwise, why would specialized governance arrangements be necessary? But the degree of incompleteness - for instance, the extent to which renegotiation procedures are specified-is endogenous. Crocker and Reynolds (1993) test the relationship between contractual incompleteness and the likelihood of opportunistic behavior in a study of Air Force engine procurement. Using a sample of procurement agreements from the 1970s and 1980s they find that contracts are more complete when the contractor has a history of disputes with purchasers and less complete when there are increases in associated intertemporal or technological uncertainty (increasing the cost of writing more complete contracts).

As Saussier (2000) points out, however, both this study and Crocker and Masten's (1991) analysis of incompleteness in natural-gas contracting rely on highly indirect measures of asset specificity. Saussier's (2000) study of French electricity contracts uses more direct measures for both physical asset specificity and site specificity, based on interviews, and finds that these are positively related to completeness, ceteris paribus. Saussier also attempts to endogenize asset specificity by employing a two-stage estimation procedure in which asset specificity is regressed on exogenous predictors in a first stage, and the fitted values used in the second-stage regression of incompleteness on asset specificity. (Correcting for endogeneity has little effect on the results).

Besides duration, price-adjustment provisions, and completeness, other contractual practices such as "take-or-pay" and exclusive-dealing provisions have been analyzed with transaction cost reasoning. An example is DeCanio and Frech's (1993) study of take-or-pay contracts in the natural gas industry. These contracts, which require the buyer to pay for some minimum quantity even if

\footnotetext{
${ }^{11}$ On natural gas contracts see also Crocker and Masten (1991), Hubbard and Weiner (1991), and Dahl and Matson (1998).
} 
delivery is not taken, are used to safeguard against buyer (pipeline) opportunism. In 1987, the Federal Energy Regulatory Commission (FERC) outlawed takeor-pay contracts. The authors used data from before and after the FERC order to test its effect on spot gas prices and prices at the wellhead. They found that FERC's interference with parties' ability to craft long-term governance mechanisms raised natural gas prices between 21 percent and 31 percent in the year following FERC's order. The results support the theory that long-term contracts add substantial value where asset specificity is high, while representing an effort to quantify that efficiency gain. ${ }^{12}$

Exclusive dealing - long regarded by economists and antitrust authorities as an anticompetitive practice-can also be explained using transaction cost reasoning. Gallick's (1984) study of the U.S. tuna industry argues that exclusive dealing is an efficient means of discouraging ex-post opportunism by fishing boat captains. Because most tuna sold in the U.S. is canned, buying a boat's output at a price reflecting average quality is cheaper for tuna processors than paying for the inspection, sorting, and grading usually found in fresh-fish markets. Exclusive dealing arrangements prevent the boat captains from selling the higher-quality tuna, ex post, to rival processors at higher prices. Exclusive dealing can enhance the efficiency of trade in other settings as well (Heide, Dutta, and Bergen, 1998).

\section{Other Hybrids}

Other hybrid forms of organization include sharing arrangements such as franchising or agricultural cropsharing; groups of firms organized as networks, clusters, or alliances; and reciprocal investments or reciprocal-trading arrangements (see Ménard, 2004, for an overview of the literature on hybrids). ${ }^{13}$ Franchising and cropsharing have each received substantial attention, both within the transaction cost and agency literatures. Under franchising, the franchisor's brand-name capital is a valuable asset (though it may or may not be specific to particular franchisees). Franchise contracts allow the franchisor to leverage this asset while retaining the high-powered incentives the franchisee would lose under vertical integration. An extensive empirical literature has tried to explain pricing arrangements such as license fees and royalty rates (Lafontaine, 1992; Bercovitz, 1999), along with specific franchising provisions such as formal procedural rules, standardization of inputs and outputs, and centralization of core functions like training and information technology (Dnes, 1996; Lafontaine and Slade, 1997; Lafontaine and Raynaud, 2002), using transaction cost and agency theory. Still, important puzzles remain; one is the coexistence of franchised and company-owned stores within the same brand. ${ }^{14}$

\footnotetext{
${ }^{12}$ Mulherin (1986) and Masten and Crocker (1985) also examine "take-or-pay" contracts.

${ }^{13}$ A firm in which decision rights are highly decentralized, as described by Jensen and Meckling (1992), may also be considered a hybrid.

${ }^{14}$ On sharing arrangements in food and agriculture see Allen and Lueck (1993) and Arruñada, GonzálezDiaz, and Lopez (1996). On hybrids in agriculture more generally see the discussion in Ménard and Klein (2004).
} 
Firms may also organize themselves into networks, groups that pool resources but often rely on relational contracts, rather than formal written agreements, to coordinate their behavior. Networks are particularly important in agriculture, where an increasing emphasis on quality control necessitates tight coordination among members of the vertical production process (Ménard, 1996). Formal ties can also help firms realize the agglomeration economies that result from knowledge and other geographic spillovers (Porter, 2000). Transaction cost reasoning helps explain the observed variety of network structures (Ménard, 1996) as well as the specific contractual arrangements used by network (or formal alliance) partners to protect specific investments (Oxley, 1997). Still, we know relatively little about the efficiency of networks and alliances relative to integrated firms and the rules network members use to govern the returns to shared resources. Another important question is whether networks are a stable mode of organization, or a transitional form, eventually giving way to more consolidated (or fragmented) structures (Ménard and Klein, 2004).

Another way for parties to protect their relationship-specific investments is by making other, "offsetting" investments. Heide and John (1988) provide an example from marketing. To service a particular manufacturer, sales agencies typically make investments specific to that manufacturer-most often, a human-capital investment in developing a sales territory for the manufacturer's product. Because agencies are small compared with manufacturers, they cannot safeguard their investments by backwards integration into manufacturing. Similarly, they lack the bargaining power to demand long-term contracts with manufacturers. Instead, they protect their relationship-specific assets by making other specific investments, namely in routines or procedures that tie or "bond" them with a manufacturer's customers. These might involve establishing personal relationships with the customers, developing an identity separate from the manufacturer's particular product, or creating specialized procedures for ordering, shipping, and servicing the product. In this way they "balance their dependence" on the manufacturer with the customers' dependence on them. ${ }^{15}$

\section{Informal Agreements}

As mentioned above, contractual relations need not be fully formal and explicit; trading arrangements are often governed by less formal, relational norms. Palay $(1984,1985)$ studies the role of informal, legally unenforceable agreements between rail-freight carriers and shippers. Shipment of items like automobile parts and chemicals, for example, requires specially designed rail cars and equipment that cannot be easily redeployed for other uses. Because vertical integration was prohibited by regulation, informal agreements emerged to protect these relationship-specific investments. Wilson (1980) shows how the New England fresh-fish market works through mutual dependence created by the particular trade arrangements there, governed by reputation. Acheson's (1985) study of

\footnotetext{
15 "Countertrade" agreements appear to perform a similar function (Hennart, 1989).
} 
the Maine lobster market reaches similar conclusions, finding the lobster market to be characterized by long-term, informal relationships between fishermen and lobster-pound operators. ${ }^{16}$

Baker, Gibbons, and Murphy (2001) show, more generally, how relational contracting - both between and within firms - differs from formal contracting. Relational contracts have the advantage that outcomes need not be verifiable to third parties, such as courts, to limit parties' incentives to behave opportunistically. On the other hand, the absence of third-party participation means that such agreements must be self-enforcing. ${ }^{17}$ Heide and John's (1992) study of buyer-supplier relations finds that relational norms often substitute for vertical integration as a means of protecting specific assets; Anderson and Weitz (1992) and Brown, Dev, and Lee (2000) show that such norms are also important in marketing.

\section{Other Examples}

Other examples of vertical relations studied within the transaction cost framework include tie-ins and "block booking" (Kenney and Klein, 1983), multinational corporations (Hennart, 1989; Yarbrough and Yarbrough, 1987b; Gatignon and Anderson, 1988; Klein, Frazer, and Roth, 1990; Hu and Chen, 1993; Henisz, 2000), company towns and company stores (Fishback, 1986, 1992), the rise of medieval marketplaces and towns (Bindseil and Pfeil, 1999), and even marriage (Hamilton, 1999). These and other "non-standard" contracting practices, when viewed through a transaction cost lens, often turn out to have efficiency properties, particularly in offering safeguards for specific investments.

\section{Challenges AND DiReCtions FOR FuRTHER RESEARCH}

The vast empirical literature on the make-or-buy decision, including the structure of long-term contracts and hybrid forms of organization, is largely consistent with the transaction cost theory of the firm: vertical arrangements are usually best understood as attempts to protect trading partners from the hazards of exchange under incomplete contracting. As Joskow (1991, p. 47) observes, the literature on the make-or-buy decision is in many ways in "much better shape than much of the empirical work in industrial organization generally."18 However, important challenges, puzzles, and opportunities remain. First, the

\footnotetext{
${ }^{16}$ Informal agreements and norms in eighteenth- and nineteenth-century whaling have been studied similarly by Ellickson (1989) and Gifford (1993).

${ }^{17}$ Self-enforcing agreements can be interpreted as noncooperative Nash equilibria in a set of repeated games; such agreements have been called "norms" (Ullman-Margalit, 1977), "conventions" (Sugden, 1986), and "social institutions" (Schotter, 1981). Ellickson's (1991) study of relationships between cattle ranchers and farmers in Shasta County, California shows that social norms (what he calls "customary law") can be superior to administrative or judicial dispute resolution among people with close social ties.

${ }^{18}$ Williamson (1996a, p. 55) puts it bluntly: "Transaction cost economics is an empirical success story."
} 
measurement and definition of asset specificity, uncertainty, and other variables remains inconsistent. Second, many studies do not explicitly compare rival explanations for vertical relationships. Third, correlation between transactional attributes and governance structures is often mistaken for causality. Fourth, the legal and regulatory environments do not always get sufficient attention.

\section{Measurement and Definition}

As mentioned above, empirical research on make-or-buy decisions is often hampered by confusion about the definitions of, and therefore the empirical proxies for, key variables such as asset specificity and uncertainty. Asset specificity is difficult to measure consistently across industries, partially explaining why there are far more single-industry studies of vertical boundaries than cross-industry studies. Uncertainty is hard to define, let alone measure. ${ }^{19}$ Moreover, empirical studies sometimes treat uncertainty as an independent variable, regressing the choice of organizational form on the variance of sales or another variable, but without including any measure of asset specificity in the model. Absent fixed investments, however, transaction cost economics does not predict that uncertainty would itself lead to hierarchical governance. Changes in circumstances only allow for expropriation where there are quasi-rents at risk; that is, where one side's investment is exposed. Where there are no relationship-specific investments at stake, it may be less costly for a firm to contract on the market for goods and services in an uncertain environment than to assume the risk of producing them internally. In this way, the effect of uncertainty depends on competitive conditions. If there is no asset specificity and thus there are many potential suppliers of a component for which future demand is uncertain, it may be cheaper to buy the component than to make it internally. ${ }^{20}$

Asset specificity has been more successfully treated in the empirical literature; relationship-specific physical, site and human capital investments have all been studied, both independently and comparatively. However, further refinement and analysis needs to be done here, particularly concerning measurement. Proxies such as capital intensity or fixed costs are very imperfect and may not capture

\footnotetext{
${ }^{19}$ As discussed above, the empirical literature on vertical integration tends to use fairly crude measures of uncertainty (such as the variation of sales). Distinctions between systemic and idiosyncratic risk, between demand and supply (or technological) risk, and between risk and Knightian uncertainty have rarely been addressed.

${ }^{20}$ In some situations uncertainty is so great that efficient governance structures cannot be crafted at all, in which case trade may fail to materialize. While there is a considerable stream of theoretical literature, following Akerlof (1970), on the possibility that markets might break down due to private information, there is relatively little theoretical or empirical work on non-market exchange under these conditions. An exception is Wiggins and Libecap's (1985) study of unitization agreements in oil production. Under such an agreement producers designate a single firm to develop a given field, with the net returns shared among all producers. This reduces recovery costs and improves oil yields by eliminating the negative externalities associated with concurrent independent development of a single field. Yet very few oil fields are unitized. Wiggins and Libecap argue that asymmetric information encourages opportunistic holdout strategies that have usually prevented the agreements from being signed.
} 
whether the investment has value outside the transaction for which it was initially made. ${ }^{21}$ Another concern is that asset-specificity effects may be confused with market power. While specific investment may lead to bilateral monopoly, a small-numbers bargaining situation is not by itself evidence of relationshipspecific investment.

\section{The Role of Asset Specificity}

While the early transaction cost literature emphasized asset specificity as the key to an efficiency explanation for vertical integration, several studies use transaction cost and incomplete-contracting theory to explain vertical integration in the absence of asset specificity. Pirrong (1993) argues that long-term contracts (and sometimes vertical integration) can be efficient in the presence of smaller contracting hazards - even when physical, human, and site asset specificities are absent. In a study of bulk shipping, he finds that more integrated governance structures can dominate spot trading in the presence of what Masten, Meehan, and Snyder (1991) call "temporal specificities." When a processing or refinery plant contracts with a particular bulk carrier, for example, both plant and carrier capacities suddenly become specific assets. Small delays in delivery can then result in large losses of quasi-rents for the plant, just as the plant's refusal to take full delivery can impose substantial losses on the carrier. To avoid costly strategic bargaining, then, these parties will choose a complex, long-term agreement. Martinez (2002) shows how temporal specificities lead to tight vertical coordination in poultry and egg production.

Three recent studies of the U.S. trucking market also find long-term contracts in the absence of asset specificity. Both Williamson (1985, p. 54) and Klein, Crawford, and Alchian (1978, p. 244) cite trucks as clear examples of durable, but nonspecific, assets. Yet, as shown by Hubbard (1999) and Nickerson and Silverman (2003), trucking continues to be characterized by tight vertical coordination between hired drivers and shippers, rather than market-based coordination between independent owner-operators and shippers, even after the industry was deregulated in the 1970s. Hubbard (1999) uses this evidence to challenge the scope of holdup theories more generally. Nickerson and Silverman (2003) show that the need for temporal coordination among hauls, and the shipper's desire to protect its brand-name capital, leads to tight vertical control, explaining why many shippers continue to use company-owned trucks. Lafontaine and Masten (2002) argue that the observed variation in contractual arrangements in trucking can best be explained by driver and truck heterogeneity, not asset specificity or marginal incentive considerations.

None of these studies denies that physical asset specificity and site specificity are important determinants of vertical relations, only that some cases of vertical

\footnotetext{
${ }^{21}$ The same applies to measures of human asset specificity, such as training, used to explain labor outsourcing (see, for example, Masters and Miles, 2002).
} 
control can be explained without reference to them, or to holdup problems at all. At present, these results appear as exceptions to a more general rule. Still, an accumulation of such anomalies could challenge the key underlying structure of the transaction cost approach.

\section{Comparing Rival Explanations}

Besides these difficulties of measurement and definition, and the role of key independent variables, empirical research on vertical boundaries is also subject to the problem found in empirical work generally: alternate hypotheses that could also fit the data are rarely stated and compared. Usually, the data are found only consistent or inconsistent with the hypothesis at hand. Undoubtedly, studies that explicitly compare competing, observationally distinct hypotheses about contractual relationships are needed, because rival theories commonly posit mutually exclusive outcomes.

One example is Spiller's (1985) comparison of asset-specificity and marketpower explanations for vertical mergers, explanations that have rival predictions about the size of the gains from mergers under various competitive conditions. While transaction cost theory predicts that the gains from merger should be increasing in the degree of asset specificity, market-power considerations suggest that the gains will be increasing in the degree of supplier-market concentration. Using site specificity, defined as the proximity of the merging firms, to represent asset specificity, Spiller studies the gains from merger according to unexpected changes in the firms' stock prices at the announcement of the merger. He finds the total gain from merger to be smaller where the distance between the merging firms is greater (i.e., where site specificity is lower). He also finds no significant relationship between industry concentration and the distance between merging firms. These findings appear to support the asset-specificity explanation over the market-power explanation.

Poppo and Zenger's (1995) investigation of transaction cost and resourcedbased explanations for information-technology (IT) outsourcing represents another comparative study. They use a survey of corporate IT managers to measure perceived satisfaction with both outsourced and in-house IT services. Consistent with transaction cost reasoning, they find that asset specificity is negatively related to the performance of market transactions. Contrary to the resourcebased view (and specific predictions offered by Ghoshal and Moran, 1996, for example), they find that asset specificity does not improve the performance of in-house transactions. (Some findings are consistent with both theories.) Other studies that assess both transaction cost and rival theories include Poppo and Zenger (1998), Silverman (1999), and Nickerson, Hamilton, and Wada (2001). Most of these comparative studies appear in the strategic management literature, where theories of the firm based on capabilities, power, and trust are important rivals to the transaction cost view. In industrial organization, by contrast, theories of vertical boundaries built on market power or technological foundations have not inspired much empirical research. 
Moreover, while the evidence presented in this chapter is often interpreted as supportive of both (a) the transaction cost theory as explicated by Williamson and Klein, Crawford, and Alchian and (b) the more formal version (the "property rights approach") associated with Grossman, Hart, and Moore, there are important differences between these two sets of explanations for firm boundaries. (See Williamson, 2000, pp. 605-07 for a detailed discussion of these differences.) For example, property-rights models focus exclusively on ex ante underinvestment in relationship-specific human capital brought about by inefficient ownership arrangements, while transaction cost theories look more at the ex post contract-execution stage. Partly because ex post contractual problems are easier to observe than ex ante human capital underinvestment-How, for instance, is optimal investment to be measured? - there have been relatively few empirical studies explicitly in the property-rights tradition. ${ }^{22}$ Whinston (2000) argues that the empirical evidence described above is not necessarily consistent with the property-rights approach. As he points out, in property-rights models the level of appropriable quasi-rents is not relevant for the integration decision; only marginal quasi-rents matter. Few empirical studies make this distinction. Furthermore, property-rights models offer specific predictions on the direction of integration (whether buyer acquires seller or seller acquires buyer), a distinction that is also generally ignored in the empirical literature.

\section{Causality}

A more general concern is that most of the empirical studies discussed here establish correlations, not causal relations, between asset specificity and internal governance. These studies typically test a reduced-form model where the probability of observing a more hierarchical form of governance increases with the degree of relationship-specific investments. Plausibly, if the presence of such investments reduces the costs of internal organization, then asset specificity could lead to integration, independent of the holdup problem or other maladaptation costs (Masten, 1994, p. 10). Masten, Meehan and Snyder (1991) attempt to distinguish these two effects in the context of human capital. They find that specific human capital investments appear to reduce internal governance costs more than they increase market governance costs. Further studies of this type would be valuable in assessing the implications of the evidence for the reduced-form version of the basic theory. However, we do not yet have a general theory of how relationship-specific assets might reduce the costs of internal organization. By contrast, the underinvestment problem associated with specific assets and market governance is fairly well understood.

\footnotetext{
${ }^{22}$ Hart (1995, p. 49) remarks that there has been "no formal testing of the property rights approach." (By "formal testing" he presumably excludes case studies.)
} 


\section{The Regulatory and Legal Environment}

Contracting takes place "in the shadow of the law" (Cooter, Marks and Mnookin, 1982), and the empirical work on vertical boundaries could be improved by greater attention to the effects of the regulatory and legal environments. With notable exceptions (like the work on contracting among public utilities and their suppliers), the literature has generally focused on relatively unregulated industries operating under a relatively stable legal regime. However, differences in regulatory structures, or how judges interpret contractual clauses, can have substantial effects on the performance of alternative vertical arrangements. Neglecting such differences leads to biased estimates of the effects of other factors, such as asset specificity and uncertainty, on the decision to vertically integrate or to use long-term contracts.

Recent papers by Henisz (2000), Delios and Henisz (2000), and Henisz and Zelner (2001) have begun looking more closely at the relationship between contractual hazards and political hazards. Henisz's (2000) study of foreign investment finds that firms tend to prefer joint ventures with foreign partners rather than majority owned plants where political hazards are high, even though majority ownership may better mitigate the contractual hazards associated with asset specificity. The available contracting options may also be limited by regulation. Moreover, as discussed above, Palay $(1984,1985)$ shows that informal agreements can substitute for regulation when vertical integration is prohibited. Loredo and Suárez (2000) study the coal-burning electricity plants in Spain and find that the opportunism was mitigated by the regulatory compact between firms and the state, instead of the long-term contracts used by U.S. plants. Ménard and Klein (2004) compare vertical relations in U.S. and European agriculture and suggest that the variation is partly explained by differences in the institutional environment.

The evolution of contractual relations in rapidly changing environments, such as transition economies, is another important area (see Boger, Hobbs, and Kerr, 2001 , for one example). These settings not only allow for comparative analysis, but also provide insight into the ability of various contractual arrangements to adapt to changing circumstances.

\section{CONCLUSION}

Despite the ongoing challenges described above, the transaction cost theory of the firm has had remarkable success in explaining the vertical structure of the enterprise. Indeed, the empirical literature on the make-or-buy decision is generally considered one of the best-developed parts of the new institutional economics. The recent survey by Boerner and Macher (2002) estimates the number of empirical papers in transaction cost economics at over 600, and a large share of these focus on vertical integration. As Williamson (2000, p. 607) 
remarks, "Those who have done this modest, slow, molecular, definitive work deserve enormous credit."

What lessons have we learned from this literature? First, asset specificity is an important determinant of vertical contractual relations. It is not the sole determinant, however; even in the face of uncertainty, arms-length contracting may effectively protect parties' relationship-specific investments. Tight vertical coordination or control may also generate efficiencies unrelated to the protection of specific assets.

Indeed, paradigmatic cases like the acquisition of Fisher Body by G.M. continue to generate controversy about the role of asset specificity compared to other contractual or organizational considerations. Still, the transaction cost approach remains the dominant framework within which such debates take place. No rival theory has produced a body of evidence remotely rivaling the transaction cost explanation for vertical integration. Market power theories continue to be relevant, particularly in the antitrust literature, but are substantially less influential today than two or three decades ago. The resource-based or capabilities view of firm boundaries is important, perhaps even dominant, within the strategic-management literature, but it has not generated a substantial body of empirical work. This is not to deny that some of the evidence usually taken to support the transaction cost approach may also be consistent with these or other alternative approaches. Indeed, as discussed above, relatively few studies attempt to distinguish among rival explanations. Much more comparative work is needed to address this concern.

A related issue is that most new theoretical work in economics on firm boundaries builds on the incomplete-contracting framework of Grossman, Hart, and Moore, not the closely related - but not identical—-transaction cost framework of Williamson and Klein, Crawford, and Alchian. As explained above, the former does not lend itself to empirical testing as easily as the latter. However, the formal language in which the Grossman-Hart-Moore theory is expressed is more in tune with contemporary economic theorizing than the mostly informal language of the transaction cost approach. If the Grossman-Hart-Moore framework comes to displace the transaction cost framework, the relevance of the empirical evidence highlighted in this chapter may be called into question. On the other hand, the difficulty in finding empirical support for incomplete-contracting models may ultimately limit their popularity. Moreover, new formalizations of transaction cost economics are beginning to emerge (for example, Bajari and Tadelis, 2001).

A second lesson is that vertical relations are often subtle and complex. While early empirical work on transaction cost determinations of vertical integration tended to focus on black-and-white distinctions between "make" or "buy," researchers increasingly recognize that a wide variety of contractual and organizational options are available; there are many shades of gray. The literature on hybrids has grown dramatically in the last ten years, while there are fewer studies of mundane issues such as outsourcing versus in-house production per se.

Third, while we know much about the transaction cost determinants of vertical relations, we know relatively little about the relation between the costs 
of contracting and organization and the wider legal, political, and social environments. The progression from single-industry case studies to cross-industry, within-country analyses, to cross-country investigations is a natural one (we see it in empirical corporate finance, for example; see the chapter by Roe in this volume). Comparisons of institutional arrangements across institutional environments may become the next growth area in the transaction cost literature.

\section{ACKNOWLEDGEMENT}

I am grateful to Tom Gibel, Claude Ménard, Mary Shirley, Mike Sykuta, and three anonymous referees for helpful suggestions.

\section{REFERENCES}

Akerlof, George A. 1970. "The Market for 'Lemons': Qualitative Uncertainty and the Market Mechanism," Quarterly Journal of Economics 84, pp. 488-500.

Alchian, Armen A., and Harold Demsetz. 1972. "Production, Information Costs, and Economic Organization," American Economic Review 62, pp. 777-95.

Anderson, Erin. 1985. "The Salesperson as Outside Agent or Employee: A Transaction Cost Analysis," Marketing Science 4, pp. 234-54.

Anderson, Erin, and David C. Schmittlein. 1984. "Integration of the Sales Force: An Empirical Examination," Rand Journal of Economics 15, pp. 385-95.

Anderson, Erin, and A.T. Coughlan. 1987. "International Market Entry and Expansion via Independent or Integrated Channels of Distribution," Journal of Marketing 51, pp. 71-82.

Armour, Henry O., and David J. Teece. 1980. "Vertical Integration and Technological Innovation," Review of Economics and Statistics 62, pp. 470-74.

Arruñada, Benito, Manuel Gonzalez-Diaz, and Begona Lopez. 1996. "The Role of Competition in Controlling Team Production: The Case of Fishing Industry," Working paper, University Pompeu Fabra.

Bajari, Patrick, and Steven Tadelis. 2001. "Incentives versus Transactions Costs: A Theory of Procurement Contracts," Rand Journal of Economics 32, pp. 387-407.

Baye, Michael, and Richard Beil. 1994. Managerial Economics and Business Strategy. Burr Ridge, Ill.: Irwin.

Bercovitz, Janet E. L. 1999. Having It Their Way? The Franchising Decision and the Structure of Franchise Contracts. Ph.D. dissertation, Haas School of Business, University of California, Berkeley.

Bender, Christian. 2002. "The Theory of the Firm Revisited: Changing Firm Boundaries in a New Information and Communication Environment," Working Paper, Department of International Business, University of Muenster.

Bigelow, Lyda. 2001. "Efficient Alignment and Survival in the U.S. Automobile Industry," Working Paper, Olin School of Business, Washington University, St. Louis.

Bindseil, Ulrich. 1997. "Vertical Integration in the Long Run: The Provision of Physical Assets to the London and New York Stock Exchanges," Journal of Institutional and Theoretical Economics 153, pp. 641-56.

Bindseil, Ulrich, and Christian Pfeil. 1999. "Specialization as a Specific Investment into the Market: A Transaction Cost Approach to the Rise of Markets and Towns in Medieval Germany, 800-1200," Journal of Institutional and Theoretical Economics 155, pp. 738-54.

Boger, Silke, Jill E. Hobbs, and William A. Kerr. 2001. "Supply Chain Relationships in the Polish Pork Sector," Supply Chain Management 6, pp. 74-82. 
Boot, Arnoud W. A., Todd T. Milbourn, and Anjan V. Thakor. 1999. "Megamergers and Expanded Scope: Theories of Bank Size and Activity Diversity," Journal of Banking and Finance 23, pp. 195-214.

Brickley, James A. 1999. "Incentives, Conflicts and Contractual Restraints: Evidence from Franchising," Journal of Law and Economics 42, pp. 745-74.

Brickley, James A., Clifford W. Smith, Jr., and Jerrold L. Zimmerman. 2004. Managerial Economics and Organizational Architecture. Third edition. New York: McGraw Hill-Irwin.

Brown, James R., C. S. Dev, and D. J. Lee. 2000. "Managing Marketing Channel Opportunism: The Efficacy of Alternative Governance Mechanisms," Journal of Marketing 64, pp. 51-65.

Casadesus-Masanell, Ramon, and Daniel F. Spulber. 2000. “The Fable of Fisher Body,” Journal of Law and Economics 43, pp. 67-104.

Caves, Richard E., and Ralph E. Bradburd. 1988. "The Empirical Determinants of Vertical Integration," Journal of Economic Behavior and Organization 9, pp. 265-79.

Coase, Ronald H. 1937. "The Nature of the Firm," in idem, The Firm, the Market and the Law. Chicago: University of Chicago Press.

Coase, Ronald H. 2000. "The Acquisition of Fisher Body by General Motors," Journal of Law and Economics 43, pp. 15-31.

Cooter, Robert, Stephen Marks, and Robert Mnookin. 1982. "Bargaining in the Shadow of the Law: A Testable Model of Strategic Behavior," Journal of Legal Studies 11, pp. 225-51.

Crocker, Keith J., and Scott E. Masten. 1988. "Mitigating Contractual Hazards: Unilateral Options and Contract Length," Rand Journal of Economics 19, pp. 327-43.

Crocker, Keith J., and Scott E. Masten. 1991. "Pretia Ex Machina? Prices and Process in Long-Term Contracts," Journal of Law and Economics 24, pp. 69-99.

Crocker, Keith J., and Kenneth J. Reynolds. 1993. "The Efficiency of Incomplete Contracts: An Empirical Analysis of Air Force Engine Procurement," Rand Journal of Economics 24, pp. 126-46.

Dahl, Carol A, and Thomas K. Matson. 1998. "Evolution of the U.S. Natural Gas Industry in Response to Changes in Transaction Costs," Land Economics 74, pp. 390-408.

David, Robert J. and Shin-Kap Han. 2004. "A Systematic Assessment of the Empirical Support for Transaction Cost Economics.”Strategic Management Journal 25, pp. 39-58.

DeCanio, Stephen J., and H. E. Frech. 1993. "Vertical Contracts: A Natural Experiment in Natural Gas Pipeline Regulation," Journal of Institutional and Theoretical Economics 149, pp. 370-92.

Delios, Andrew, and Witold J. Henisz. 2000. "Japanese Firms' Investment Strategies in Emerging Economies," Academy of Management Journal 43, pp. 305-23.

Dnes, Anthony. 1996. "The Economic Analysis of Franchise Contracts," Journal of Institutional and Theoretical Economics 152, pp. 297-324.

Ellickson, Robert C. 1991. Order Without Law: How Neighbors Settle Disputes. Cambridge, Mass: Harvard University Press.

Fein, A. J. and Erin Anderson. 1997. "Patterns of Credible Commitments: Territory and Brand Selectivity in Industrial Distribution Channels," Journal of Marketing 61, pp. 19-34.

Fishback, Price V. 1986. "Did Coal Miners 'Owe Their Souls to the Company Store'? Theory and Evidence from the early 1900s," Journal of Economic History 46, pp. 1011-29.

Fishback, Price V. 1992. "The Economics of Company Housing: Historical Perspectives from the Coal Fields," Journal of Law, Economics, and Organization 8, pp. 346-65.

Freeland, Robert F. 2000. "Creating Holdup Through Vertical Integration: Fisher Body Revisited," Journal of Law and Economics 43, pp. 33-66.

Friedman, Milton. 1953. "The Methodology of Positive Economics," in idem, Essays in Positive Economics (pp. 3-43. Chicago: University of Chicago Press.

Gallick, Edward C. 1984. Exclusive Dealing and Vertical Integration: The Efficiency of Contracts in the Tuna Industry. Federal Trade Commission Bureau of Economics Staff Report. Washington, D.C.: Federal Trade Commission.

Gatignon, Hubert, and Erin Anderson. 1988. "The Multinational Corporation's Degree of Control over Foreign Subsidiaries: An Empirical Test of a Transaction Cost Explanation," Journal of Law, Economics and Organization 4, pp. 305-36. 
Ghoshal, Sumantra, and Peter Moran. 1996. "Bad for Practice: A Critique of the Transaction Cost Theory," Academy of Management Review 21, pp. 13-47.

Gibbons, Robert. 2000. "Firms and Other Relationships," Working Paper, MIT Department of Economics.

Gifford, Adam, Jr. 1993. "The Economic Organization of 17th- through mid 19th-Century Whaling and Shipping. Journal of Economic Behavior and Organization 20, pp. 137-50.

Globerman, Steven, and Richard Schwindt. 1986. "The Organization of Vertically Related Transactions in the Canadian Forest Products Industries," Journal of Economic Behavior and Organization 7, pp. 199-212.

Goldberg, Victor. 1980. "Relational Exchange: Economics and Complex Contracts," American Behavioral Scientist 23, pp. 337-52.

Goldberg, Victor, and John R. Erickson. 1987. "Quantity and Price Adjustment in Long-Term Contracts: A Case Study of Petroleum Coke," Journal of Law and Economics 30, pp. 369-98.

González,-Diaz, Manuel, Benito Arruñada, and Alberto Fernández. 2000. "Causes of Subcontracting: Evidence from Panel Data on Construction Firms," Journal of Economic Behavior and Organization 42, pp. 167-87.

Grossman, Sanford J., and Oliver D. Hart. 1986. "The Costs and Benefits of Ownership: A Theory of Vertical and Lateral Integration,” Journal of Political Economy 94, pp. 691-719.

Hallwood, Paul C. 1991. "On Choosing Organizational Arrangements: The Example of Offshore Oil Gathering," Scottish Journal of Political Economy 38, pp. 227-41.

Hamilton, Gillian. 1999. "Property Rights and Transaction Costs in Marriage: Evidence from Prenuptial Contracts," Journal of Economic History 59, pp. 68-103.

Harrigan, Kathryn Rudie. 1986. "Matching Vertical Integration Strategies to Competitive Conditions," Strategic Management Journal 7, pp. 535-55.

Hart, Oliver D. 1995. Firms, Contracts, and Financial Structure. New York: Oxford University Press.

Hart, Oliver D., and John Moore. 1990. "Property Rights and the Nature of the Firm," Journal of Political Economy 98, pp. 1119-58.

Heide, J. B., and G. John. 1988. "The Role of Dependence Balancing in Safeguarding Transaction-Specific Assets," Journal of Marketing 52, pp. 20-35.

Heide, J. B., S. Dutta, and M. Bergen. 1998. "Exclusive Dealing and Business Efficiency: Evidence from Industry Practice," Journal of Law and Economics 41, pp. 387-407.

Helper, Susan, John Paul MacDuffie, and Charles F. Sabel. 2000. "Pragmatic Collaborations: Advancing Knowledge While Controlling Opportunism," Industrial and Corporate Change 9, pp. 443-83.

Henisz, Witold J. 2000. “The Institutional Environment for Multinational Investment," Journal of Law, Economics, and Organization 16, pp. 334-64.

Henisz, Witold J., and Bennett A. Zelner. 2001. "The Institutional Environment for Telecommunications Investment," Journal of Economics and Management Strategy 10, pp.

Hennart, Jean-Francois. 1988. "Upstream Vertical Integration in the Aluminum and Tin Industries," Journal of Economic Behavior and Organization 9, pp. 281-99.

Hennart, Jean-Francois. 1989. "The Transaction Cost Rationale for Countertrade," Journal of Law, Economics and Organization 5, pp. 127-53.

Holmström, Bengt, and Paul Milgrom. 1994. "The Firm as an Incentive System," American Economic Review 84, pp. 972-91.

Hu, M., and H. Chen. 1993. "Foreign Ownership in Chinese Joint Ventures," Journal of Business Research 26, pp. 500-13.

Hubbard, R. Glenn, and Robert J. Weiner. 1991. "Efficient Contracting and Market Power: Evidence from the U.S. Natural Gas Industry," Journal of Law and Economics 34, pp. 25-67.

Hubbard, Thomas N. 1999. "How Wide is the Scope of Hold-Up Based Theories of Governance? Shipper-Carrier Relations in Trucking," Working Paper, Department of Economics, UCLA.

Jensen, Michael C., and William H. Meckling. 1992. "General and Specific Knowledge, and Organizational Structure," in Lars Werin and Hans Wijkander, eds., Contract Economics. Oxford: Blackwell. 
John, George, and Barton A. Weitz. 1988. "Forward Integration into Distribution: An Empirical Test of Transaction Cost Analysis," Journal of Law, Economics and Organization 4, pp. 33755.

Joskow, Paul L. 1985. "Vertical Integration and Long Term Contracts: The Case of CoalBurning Electric Generating Plants," Journal of Law, Economics and Organization 1, pp. 3380.

Joskow, Paul L. 1987. "Contract Duration and Relationship-Specific Investments: Empirical Evidence from Coal Markets,” American Economic Review 77, pp. 168-85.

Joskow, Paul L. 1988a. "Asset Specificity and the Structure of Vertical Relationships: Empirical Evidence," Journal of Law, Economics, and Organization 4, pp. 95-117.

Joskow, Paul L. 1988b. "Price Adjustment in Long-Term Contracts: The Case of Coal," Journal of Law and Economics 31, pp. 47-83.

Joskow, Paul L. 1990. "The Performance of Long-Term Contracts: Further Evidence from the Coal Markets," Rand Journal of Economics 21, pp. 251-74.

Kenney, Roy W., and Benjamin Klein. 1983. “The Economics of Block Booking,” Journal of Law and Economics 26, pp. 497-540.

Klein, Benjamin. 1988. "Vertical Integration as Organized Ownership: The Fisher BodyGeneral Motors Relationship Revisited," Journal of Law, Economics and Organization 4, pp. 199-213.

Klein, Benjamin. 2000. "Fisher-General Motors and the Nature of the Firm," Journal of Law and Economics 43, pp. 105-41.

Klein, Benjamin, Robert A. Crawford, and Armen A. Alchian. 1978. "Vertical Integration, Appropriable Rents, and the Competitive Contracting Process," Journal of Law and Economics 21, pp. 297-326.

Klein, Peter G., and Sandra K. Klein. 2002. "Do Entrepreneurs Make Predictable Mistakes? Evidence from Corporate Divestitures," in Nicolai J. Foss and Peter G. Klein, eds., Entrepreneurship and the Firm (Aldershott, U.K.: Edward Elgar).

Klein, Saul, Gary L. Frazier, and Victor J. Roth. 1990. "A Transaction Cost Analysis Model of Channel Integration in International Markets," Journal of Marketing Research 27, pp. 196208.

Lafontaine, Francine. 1992. "Agency Theory and Franchising: Some Empirical Results," Rand Journal of Economics 23, pp. 263-83.

Lafontaine, Francine, and Kathrin Shaw. 1999. "The Dynamics of Franchise Contracting: Evidence from Panel Data," Journal of Political Economy 107, pp. 1041-80.

Lafontaine, Francine, and Margaret Slade. 1997. "Retail Contracting: Theory and Practice," Journal of Industrial Economics 45, pp. 1-25.

Lafontaine, Francine, and Emmanuel Raynaud. 2002. "The Role of Residual Claims and SelfEnforcement in Franchise Contracting," NBER Working Paper 8868.

Lafontaine, Francine, and Scott E. Masten. 2002. "Contracting in the Absence of Specific Investments and Moral Hazard: Understanding Carrier-Driver Relations in U.S. Trucking," Working Paper, University of Michigan Business School.

Langlois, Richard N., and Paul L. Robertson. 1989. "Explaining Vertical Integration: Lessons from the American Automobile Industry," Journal of Economic History 49, pp. 36175.

Levy, David. 1985. "The Transaction Cost Approach to Vertical Integration: An Empirical Examination," Review of Economics and Statistics 67, pp. 438-45.

Lieberman, Marvin B. 1991. "Determinants of Vertical Integration: An Empirical Test," Journal of Industrial Economics 39, pp. 451-66.

Loredo, Enrique, and Eugenia Suárez. 2000. “The Governance of Transactions: Joskow's CoalBurning Generating Plants Example Revisited,” Energy Policy 28, pp. 107-14.

Lyons, Bruce R. 1995. "Specific Investment, Economies of Scale, and the Make-or-Buy Decision: A Test of Transaction Cost Theory," Journal of Economic Behavior and Organization 26, pp. 431-43. 
MacDonald, James M. 1985. "Market Exchange or Vertical Integration: An Empirical Analysis," Review of Economics and Statistics 67, pp. 327-31.

Macher, Jeffrey T. 2001. "Vertical Disintegration and Process Innovation in Semiconductor Manufacturing: Foundries vs. Integrated Device Manufacturers," Working Paper, McDonough School of Business, Georgetown University.

MacMillan, Ian C., Donald C. Hambrick, and Johannes M. Pennings. 1986. "Uncertainty Reduction and the Threat of Supplier Retaliation: Two Views of the Backward Integration Decision," Organization Studies 7, pp. 263-78.

Martinez, Steve.W. 2002. "A Comparison of Vertical Coordination in the U.S. Poultry, Egg, and Pork Industries," Current Issues in Economics of Food Markets, Agriculture Information Bulletin No. 747-05, U.S. Department of Agriculture, Economic Research Service.

Masten, Scott E. 1984. "The Organization of Production: Evidence from the Aerospace Industry," Journal of Law and Economics 27, pp. 403-17.

Masten, Scott E. 1994. "Empirical Research in Transaction-cost Economics: Challenges, Progress, Directions," Mimeo, University of Michigan Business School.

Masten, Scott E., ed. 1996. Case Studies in Contracting and Organization. New York: Oxford University Press.

Masten, Scott E., and Keith J. Crocker. 1985. "Efficient Adaptation in Long-Term Contracts: Take-or-Pay Provisions for Natural Gas," American Economic Review 75, pp. 1083-93.

Masten, Scott E., James W. Meehan, and Edward A. Snyder. 1989. "Vertical Integration in the U.S. Auto Industry: A Note on the Influence of Specific Assets," Journal of Economic Behavior and Organization 12, pp. 265-73.

Masten, Scott E., James W. Meehan, and Edward A. Snyder. 1991. "The Costs of Organization," Journal of Law, Economics and Organization 7, pp. 1-25.

Masten, Scott E., and Edward A. Snyder. 1993. "United States versus United Shoe Machinery Corporation: On the Merits," Journal of Law and Economics 36, pp. 33-70.

Masten, Scott E., and Stéphane Saussier. 2000. "Econometrics of Contracts: An Assessment of Developments in the Empirical Literature on Contracting," Revue d'Economie Industrielle: 215-36.

Masters, John K., and Grant Miles. 2002. "Predicting the Use of External Labor Arrangements: A Test of the Transaction Cost Perspective," Academy of Management Journal 45, pp. 43142.

Matsusaka, John G. 2001. "Corporate Diversification, Value Maximization, and Organizational Capabilities," Journal of Business 74, pp. 409-31.

Ménard, Claude. 1996. "On Clusters, Hybrids and other Strange Forms. The Case of the French Poultry Industry," Journal of Institutional and Theoretical Economics 152, pp. 15483.

Ménard, Claude. 2004. "The Economics of Hybrid Organizations," Journal of Institutional and Theoretical Economics 160, pp. 1-32.

Ménard, Claude, and Peter G. Klein. 2004. "Organizational Issues in the Agri-Food Sector: Toward a Comparative Approach," American Journal of Agricultural Economics, 86, pp. 746-751.

Milgrom, Paul A., and John Roberts. 1990. "Bargaining Costs, Influence Costs, and the Organization of Economic Activity," in James E. Alt and Kenneth A. Shepsle, eds., Perspectives on Positive Political Economy. Cambridge: Cambridge University Press.

Monteverde, Kirk, and David J. Teece. 1982a. "Appropriable Rents and Quasi-Vertical Integration," Journal of Law and Economics 25, pp. 321-28.

Monteverde, Kirk, and David J. Teece. 1982b. "Supplier Switching Costs and Vertical Integration in the Automobile Industry," Bell Journal of Economics 13, pp. 206-13.

Mosakowski, Elaine. 1997. "Strategy Making Under Causal Ambiguity: Conceptual Issues and Empirical Evidence,” Organization Science 8, pp. 414-42. 
Mulherin, J. Harold. 1986. "Complexity in Long-Term Contracts: An Analysis of Natural Gas Contractual Provisions," Journal of Law, Economics, and Organization 2, pp. 10517.

Muris, Timothy J., David Scheffman, and Pablo T. Spiller. 1992. "Strategy and Transaction Costs: The Organization of Distribution in the Carbonated Soft Drink Industry," Journal of Economics and Management Strategy 1, pp. 83-128.

Murtha, Thomas P. 1993. "Credible Enticements: Can Host Governments Tailor Multinational Firms' Organizations to Suit National Objectives?" Journal of Economic Behavior and Organization 20, pp. 171-86.

Nelson, Richard R., and Sidney G. Winter. 1982. An Evolutionary Theory of Economic Change. Cambridge, Mass: Harvard University Press.

Nickerson, Jackson A., Barton H. Hamilton, and Tetsuo Wada. 2001. "Market Position, Resource Profile, and Governance: Linking Porter and Williamson in the Context of International courier and Small Package Services in Japan. Strategic Management Journal 22, pp. 251-73.

Nickerson, Jackson A., and Brian S. Silverman. 2003. "Why Aren’t All Truck Drivers OwnerOperators? Asset Ownership and the Employment Relation in Interstate For-Hire Trucking. Journal of Economics and Management Strategy 12, pp. 91-118.

Ohanian, Nancy Kane. 1994. "Vertical Integration in the U.S. Pulp and Paper Industry, 19001940," Review of Economics and Statistics 74, pp. 202-07.

Oxley, Joanne E. 1997. "Appropriability Hazards and Governance in Strategic Alliances: A Transaction Cost Approach," Journal of Law, Economics, and Organization 13, pp. 387-409.

Oxley, Joanne E. 1999. "Institutional Environment and the Mechanisms of Governance: The Impact of Intellectual Property Protection on the Structure of Inter-firm Alliances," Journal of Economic Behavior and Organization 38, pp. 283-309.

Palay, Thomas M. 1984. "Comparative Institutional Economics: The Governance of Rail Freight Contracting," Journal of Legal Studies 13, pp. 265-87.

Palay, Thomas M. 1985. "Avoiding Regulatory Constraints: Contracting Safeguards and the Role of Informal Agreements," Journal of Law, Economics, and Organization 1, pp. $155-76$.

Pirrong, Stephen Craig. 1993. "Contracting Practices in Bulk Shipping Markets: A Transactions Cost Explanation," Journal of Law and Economics 36, pp. 937-76.

Pisano, Gary P. 1990. "Using Equity Participation to Support Exchange: Evidence from the Biotechnology Industry," Journal of Law, Economics and Organization 5, pp. 109-26.

Poppo, Laura, and Todd Zenger. 1995. "Opportunism, Routines, and Boundary Choices: A Comparative Test of Transaction Cost and Resource-based Explanations for Make-or-Buy Decisions," Academy of Management Journal, Best Papers Proceedings: 42-46.

Poppo, Laura, and Todd Zenger. 1998. "Testing Alternative Theories of the Firm: Transaction Cost, Knowledge-Based, and Measurement Explanations for Make-or-Buy Decisions in Information Services," Strategic Management Journal 19, pp. 853-77.

Porter, Michael E. 2000. "Location, Competition and Economic Development: Local Clusters in a Global Economy," Economic Development Quarterly 14, pp. 15-34.

Regan, Laureen. 1997. "Vertical Integration in the Property-Liability Insurance Industry: A Transaction Cost Approach," Journal of Risk and Insurance 64, pp. 41-62.

Rindfleisch, A., and J. B. Heide. 1997. "Transaction Cost Analysis: Past, Present, and Future Applications," Journal of Marketing 61, pp. 30-54.

Sampson, Rachelle C. 2001. "The Cost of Inappropriate Governance in R\&D Alliances," Working Paper, Stern School of Business, New York University.

Saussier, Stéphane. 2000. "Transaction Costs and Contractual Incompleteness: The Case of Electricitie de France," Journal of Economic Behavior and Organization 42, pp. 189206.

Schotter, Andrew. 1981. The Economic Theory of Social Institutions. Cambridge: Cambridge University Press. 
Shelanski, Howard A., and Peter G. Klein. 1995. "Empirical Research in Transaction Cost Economics: A Review and Assessment," Journal of Law, Economics and Organization 11, pp. 335-61.

Silverman, Brian S. 1999. "Technological Resources and the Direction of Corporate Diversification: Toward an Integration of the Resource-Based View and Transaction Cost Economics," Management Science 45, pp. 1109-24.

Silverman, Brian S., Jackson A. Nickerson, and John B. Freeman. 1997. "Profitability, Transactional Alignment, and Organizational Mortality in the U.S. Trucking Industry," Strategic Management Journal 18 (Special Issue): 31-52.

Simon, Herbert A. 1992. Review of Oliver E. Williamson, ed., Organization Theory: From Chester Barnard to the Present and Beyond, in Journal of Economic Literature 30, pp. 150305 .

Spiller, Pablo. 1985. "On Vertical Mergers," Journal of Law, Economics and Organization 1, pp. 285-312.

Stuckey, John. 1983. Vertical Integration and Joint Ventures in the Aluminum Industry. Cambridge, Mass.: Harvard University Press.

Sugden, Robert. 1986. The Economics of Rights, Cooperation, and Welfare. Oxford: Blackwell. Ullman-Margalit, Edna. 1977. The Emergence of Norms. Oxford: Clarendon Press.

Ulset, Svein. 1996. "R\&D Outsourcing and Contractual Governance: An Empirical Study of Commercial R\&D Projects," Journal of Economic Behavior and Organization 30, pp. 63-82.

Vannoni, Davide. 2002. "Empirical Studies of Vertical Integration: The Transaction Cost Orthodoxy," International Review of Economics and Business 49, pp. 113-41.

Walker, Gordon, and David Weber. 1984. "A Transaction Cost Approach to Make-or-Buy Decisions," Administrative Science Quarterly 29, pp. 373-91.

Weiss, Allen M., and Nancy Kurland. 1997. "Holding Distribution Channel Relationships Together: The Role of Transaction-Specific Assets and Length of Prior Relationships," Organization Science 8(6): 612-23.

Weiss, Avi. 1992. "The Role of Firm-Specific Capital in Vertical Mergers," Journal of Law and Economics 35, pp. 71-88.

Wiggins, Steven N., and Gary D. Libecap. 1985. "Oil Field Unitization: Commercial Failure in the Presence of Imperfect Information," American Economic Review 75, pp. 368-85.

Whinston, Michael D. 2000. "On the Transaction Cost Determinants of Vertical Integration," Working Paper, Department of Economics, Northwestern University.

Williamson, Oliver E. 1975. Markets and Hierarchies: Analysis and Antitrust Implications. New York: Free Press.

Williamson, Oliver E. 1976. "Franchise Bidding for Natural Monopolies-In General and with Respect to CATV," Bell Journal of Economics 7, pp. 73-104.

Williamson, Oliver E. 1985. The Economic Institutions of Capitalism. New York: Free Press.

Williamson, Oliver E. 1988. "The Economics and Sociology of Organizatiton: Promoting a Dialogue," in George Farkas and Paula England, eds., Industries, Firms, and Jobs: Sociological and Economic Approaches. New York: Plenum Press.

Williamson, Oliver E. 1991a. "Comparative Economic Organization: The Analysis of Discrete Structural Alternatives," Administrative Science Quarterly 36, pp. 269-96.

Williamson, Oliver E. 1991b. "Strategizing, Economizing, and Economic Organization," Strategic Management Journal 23, pp. 75-94.

Williamson, Oliver E. 1993. "Opportunism and its Critics," Managerial and Decision Economics 14, pp. 97-107.

Williamson, Oliver E. 1996a. "Economic Organization: The Case for Candor," Academy of Management Review 21, pp. 48-57.

Williamson, Oliver E. 1996b. The Mechanisms of Governance. New York: Oxford University Press.

Williamson, Oliver E. 2000. "The New Institutional Economics: Taking Stock, Looking Ahead,"Journal of Economic Literature 38, pp. 595-613. 


\section{Peter G. Klein}

Wilson, James A. 1980. "Adaptation to Uncertainty and Small Numbers Exchange: The New England Fresh Fish Market," Bell Journal of Economics 4, pp. 491-504.

Yarbrough, Beth V., and Robert M. Yarbrough. 1987a. "Cooperation in the Liberalization of International Trade: After Hegemony, What?" International Organization 41, pp. 1-26.

Yarbrough, Beth V., and Robert M. Yarbrough. 1987b. "Institutions for the Governance of Opportunism in International Trade," Journal of Law, Economics and Organization 3, pp. 12939.

Yvrande-Billon, Anne. 2004. "Contractual Choices and Performances: Evidence from the British Railways." In George Hendrikse, Josef Windsperger, Gérard Cliquet, and Mika Tuunanen, eds., Economics and Management of Franchising Networks (Heidelberg: Physica/Springer, forthcoming). 